\title{
HEPATITIS B AND C IN HEALTHCARE WORKERS: PREVALENCE, RELATION TO VACCINATION AND OCCUPATIONAL FACTORS
}

\author{
Sateesh K. Malkappa ${ }^{1}$, Sreekanth B ${ }^{2}$
}

\section{HOW TO CITE THIS ARTICLE:}

Sateesh K. Malkappa, Sreekanth. B. "Hepatitis B and C in Healthcare Workers: Prevalence, Relation to Vaccination and Occupational Factors". Journal of Evolution of Medical and Dental Sciences 2014; Vol. 3, Issue 15, April 14; Page: 3919-3922, DOI: 10.14260/jemds/2014/2376

\begin{abstract}
Infection with Hepatitis B virus (HBV) and Hepatitis C virus (HCV) in occupationally exposed health care workers (HCWs) should be accepted as a realistic possibility. This study aimed at estimating prevalence of hepatitis $B$ and hepatitis $C$ virus infections among health care workers with the final goal to encourage HBV vaccination of the non-immune Indian health care worker in a tertiary hospital. A total of 219 samples were screened from November 2012 to October 2013. They were screened for the presence of hepatitis B surface antigen (HBs Ag), and anti- HCV antibodies by the third generation ELISA. The HBsAg prevalence was $1.37 \%$. Anti-HCV antibody was not detected in any of the health care worker screened. $63.47 \%$ of health care workers were not immunised. All HCWs who were positive for HBsAg were non- immunised. A moderate HBV infection rate and low $\mathrm{HBV}$ vaccination coverage were found in the study. India is a tropical country still endemic for HBV infection and new strategies to promote $\mathrm{HBV}$ vaccinations are to be adopted.
\end{abstract}

KEYWORDS: Hepatitis B \& C, Health care workers, Vaccination

INTRODUCTION: Approximately three million health care workers (HCW) are exposed to percutaneous blood each year. ${ }^{1}$ The risk of HBV infections among HCWs is four times higher than in the general population and depends on the prevalence of HBV infected patients, nature and frequency of contact with blood and body fluids, duration of employment and immunization status. A high prevalence of these infections in the general population, the large capacity of infectious virus and daily contact with biological fluids and potentially contaminated instruments are key risk factors for HCWs for the transfer of HBV and HCV infection. ${ }^{2}$ Infection with hepatitis B virus (HBV) and hepatitis $\mathrm{C}$ virus (HCV) in occupationally exposed health care workers (HCWs) should be accepted as a realistic possibility. ${ }^{3}$ Blood contains the highest HBV titres and is the most important vehicle of transmission in the health- care setting. HBV is relatively stable in the environment, remains viable for at least 7 days on environmental surfaces at room temperature. ${ }^{4}$ Screening for hepatitis B \& C is still not being performed in many health setups. Due to tremendous increase in surgical workload, operation theaters could be one of the main sources of transmission of hepatitis B \& $\mathrm{C}^{5}$. Preoperative screening for hepatitis B \& C in patients is not routinely performed even for elective surgery in our country because of multiple factors and this may pose a major risk to health care workers. Major factors are, lack of public awareness about the disease, inadequate funding for health care and poor health facilities throughout the country. Whereas the literature on hepatitis B virus infection in India is growing, there is still paucity of information on HBV and HCV among HCWs. This paper contributes to this discourse by presenting the prevalence estimates for hepatitis $B$ and hepatitis $C$ virus infections among health care workers.

MATERIAL\& METHODS: The study was carried out in department of Microbiology over a period of 1 year from November 2012 to October 2013. Serum samples were collected from all the health care 
professionals in KIMS hospital and KIDS, KIMSCON Narketpally after receiving the consent. Hepatitis B surface antigen and Anti Hepatitis $\mathrm{C}$ antibody tests were done by ELISA method using third generation ELISA kits (J. Mitra Industries India).

\section{OBSERVATIONS AND RESULTS:}

\begin{tabular}{|l|c|}
\hline \multicolumn{1}{|c|}{ Health care personnel } & Number (\%) \\
\hline Doctors: Faculty & $13(5.93)$ \\
\hline Post-Graduates & $25(11.41)$ \\
\hline Nurses & $60(27.39)$ \\
\hline Technicians & $27(12.32)$ \\
\hline Ayas & $41(18.72)$ \\
\hline Radiology technician & $12(5.47)$ \\
\hline Dentist & $35(15.98)$ \\
\hline Clerical Staff Total & $6(2.73)$ \\
\hline \multicolumn{2}{|c|}{$\quad 219$} \\
\hline
\end{tabular}

Table 1: Sample Distribution among Health Care Personnel N= 219

Three (1.37\%) out of 219 health care personnel were positive for HBsAg. Among the positives there was 1 technician, 1 nurse, and 1clerical staff. Serum samples from all health care personnel were negative for Hepatitis $\mathrm{C}$ antibodies.

\begin{tabular}{|l|c|c|c|c|}
\hline \multirow{2}{*}{ Occupation } & \multicolumn{2}{|c|}{ HBsAg } & \multicolumn{2}{c|}{ Anti-HCV } \\
\cline { 2 - 5 } & $\begin{array}{c}\mathbf{R} \\
\mathbf{n}(\%)\end{array}$ & $\begin{array}{c}\text { NR } \\
\mathbf{n}(\%)\end{array}$ & $\begin{array}{c}\mathbf{R} \\
\mathbf{n}(\%)\end{array}$ & $\begin{array}{c}\text { NR } \\
\mathbf{n}(\%)\end{array}$ \\
\hline Physician & $0(0)$ & $13(5.93)$ & $0(0)$ & $0(0)$ \\
\hline Post graduates & $0(0)$ & $25(11.41)$ & $0(0)$ & $0(0)$ \\
\hline Nurses & $1(0.45)$ & $59(26.94)$ & $0(0)$ & $0(0)$ \\
\hline Lab technician & $1(0.45)$ & $26(21.00)$ & $0(0)$ & $0(0)$ \\
\hline Radiology technician & $0(0)$ & $12(5.47)$ & $0(0)$ & $0(0)$ \\
\hline Ayas & $0(0)$ & $41(18.72)$ & $0(0)$ & $0(0)$ \\
\hline Dentist & $0(0)$ & $35(15.98)$ & $0(0)$ & $0(0)$ \\
\hline Clerical Staff & $1(0.45)$ & $5(2.28)$ & $0(0)$ & $0(0)$ \\
\hline \multicolumn{1}{|c|}{ Total } & $\mathbf{3 ( 1 . 3 7 )}$ & $\mathbf{2 1 6 ( 9 8 . 6 3 )}$ & $\mathbf{0 ( 0 )}$ & $\mathbf{0 ( 0 )}$ \\
\hline
\end{tabular}

Table 2: Relation between the occupation and rate of hepatitis $\mathrm{B}$ and $\mathrm{C}$ infection among all participants

\begin{tabular}{|c|c|c|}
\hline \multirow{2}{*}{ Vaccination } & \multicolumn{2}{|c|}{ HBsAg } \\
\cline { 2 - 3 } & $\begin{array}{c}\mathbf{R} \\
\mathbf{n}(\%)\end{array}$ & $\begin{array}{c}\mathbf{N R} \\
\mathbf{n}(\%)\end{array}$ \\
\hline Yes & $0(0)$ & $77(35.15)$ \\
\hline No & $3(1.37)$ & $139(63.47)$ \\
\hline
\end{tabular}

Table 3: The relation between the prevalence of HBsAg and anti-HCV and Vaccination of participants 


\begin{tabular}{|l|c|c|c|}
\hline \multicolumn{1}{|c|}{ Study } & Total no of HCW's & HBsAg Positives & anti-HCV Positives \\
\hline Abdelsalam Nail et al. $^{1}$ & 211 & $5(2.4 \%)$ & $0(0 \%)$ \\
\hline Mirsad Cabaravdic et al $^{2}$ & 3,330 & $49(1.47 \%)$ & $11(0.3 \%)$ \\
\hline Ziraba et al $^{3}$ & 370 & $30(8.1 \%)$ & - \\
\hline Mirza Khalil Bahmani et al $^{4}$ & 346 & $9(2.6)$ & - \\
\hline Luiz A.S. Ciorlia et al $^{6}$ & 1,433 & $11(0.8 \%)$ & - \\
\hline Rola I. Jadallah et al $^{7}$ & 52 & $05(0.96)$ & - \\
\hline Bo-Moon Shin et al $^{8}$ & 571 & $14(2.4 \%)$ & $0(0 \%)$ \\
\hline $\begin{array}{l}\text { Anand Kalaskar } \\
\text { and Mahesh Kumar }\end{array}$ & 442 & $5(1.13 \%)$ & $5(1.3 \%)$ \\
\hline Zakaria Astal et al $^{10}$ & 399 & $11(2.8 \%)$ & $2(0.8 \%)$ \\
\hline Baldo V, Floreani A et al ${ }^{11}$ & 245 & $1(0.4 \%)$ & $(0.87 \%)$ \\
\hline Duseja A, Arora L, et al ${ }^{12}$ & 3556 & $61(1.7 \%)$ & $0(0 \%)$ \\
\hline Ganju S A, Goel A. ${ }^{13}$ & 200 & $5 \%$ & - \\
\hline
\end{tabular}

Table 4: Prevalence of HBsAg and anti- HCV in health care professionals from Various Studies

DISCUSSION: Health care personnel are at risk for blood borne pathogens like hepatitis B and C. The study was done to screen HBsAg and antibodies to hepatitis $\mathrm{C}$ among health care personnel by using ELISA. All the samples were collected in asymptomatic health care personnel. Three out of 219 $(1.37 \%)$ health care personnel were positive for HBsAg. This is comparable with previous studies.1,2, $4,5,7,8,9,12$ None of the samples were positive for antibodies to HCV1,9,13. All the above three HBsAg positive participants were not vaccinated for hepatitis B. Among these three positive cases two revealed past history of jaundice. This could be prevented by vaccination. By following strict universal safety precautions which includes vaccination against hepatitis $B$, transmission of these blood borne pathogens can be reduced.

CONCLUSION: Health care providers are at risk of getting hepatitis B and C and they can also become source of infection to others. Regular screening for these pathogens once in six months, in the hospitals is essential to prevent the risk of transmission of these infections to others. Early diagnosis during asymptomatic period can be made easily and proper treatment can be instituted. Sensitization programmes about universal safety precautions are to be organised regularly to all health care workers.

\section{BIBLIOGRAPHY:}

1. Abdelsalam Nail, Siham Eltiganni, Abdelmageed Imam. Seroprevalence of Hepatitis B and C among health care workers in Omdurman, Sudan. Sudan JMS Sept 2008; 201- 5.

2. Mirsad Cabaravdic, Mihreta Delic, Eti Obaran, Sedina Sahman. Prevalence of Hepatitis-B Surface Antigen (HBs-Ag) and anti-HCV Antibody among Health Care Workers of Canton Sarajevo (Bosnia and Herzegovina).

3. Abdhalah K Ziraba, Josephine Bwogi, Alice Namale, Caroline W Wainaina, Harriet MayanjaKizza. Sero-prevalence and risk factors for hepatitis B virus infection among health care workers in a tertiary hospital in Uganda. BMC Infectious Diseases2010; 10:191- 202. 
4. Mirza Khalil Bahmani, Ayyoob Khosravi, Adel Mobasser, Eslam Ghezelsofla. Seroprevalence of hepatitis B virus infection and vaccination compliance among health care workers in Fars Province, Iran. Iranian Journal of Clinical Infectious Diseases 2010; 5(1):45-50.

5. Bongomin Pido, Magid Kagimu. Prevalence of hepatitis B virus (HBV) infection among Makerere University medical students. African Health Sciences2005; 5(2):92 -98.

6. Luiz A.S. Ciorliad, Dirce M.T. Zanetta. Hepatitis B in Healthcare Workers: Prevalence, Vaccination and Relation to Occupational Factors. The Brazilian Journal of Infectious Diseases 2005; 9(5):384-389.

7. Rola I. Jadallah, Ghaleb M. Adwan, Nael S. Abu-Hasan, Kamel M. Adwan. Prevalence of hepatitis B virus markers among high risk groups in Palestine. Medical Journal of Islamic World Academy of Sciences 2005; 15(4):157-60.

8. Bo-Moon Shin, Hyeon Mi Yoo, Ae Sook Lee, Sang Keun Park. Sero- prevalence of Hepatitis B virus among health care workers in Korea. Korean Med Sci 2006; 2:58-62.

9. Anand Kalaskar, Mahesh Kumar. Prevalence of Hepatitis B and Hepatitis C Viruses among Nurses and nursing students in a Medical College Hospital in Southern Tamil Nadu, India. Int Res J Microbiol 2012; 3(1):10-13.

10. Zakaria Astal, Majdy Dhair. Serologic evaluation for Hepatitis B and C among health care workers in southern Gaza strip (Palestine). Journal of Islamic university of Gaza 2004;12(1): 153-64.

11. Baldo V, Floreani A, Dal Vecchio L, Cristofoletti M, Carletti M, Majori S, et al. Occupational risk of blood-borne viruses in healthcare workers: a 5-year surveillance program. Infect Control Hosp Epidemiol2002; 23:325-27.

12. Duseja A, Arora L, Masih B, Singh H, Gupta A, Behera D, Chawla YK, Dhiman RK. Hepatitis B and $C$ virus - prevalence and prevention in health care workers. Trop Gastroenterol.2002; 23:12526.

13. Ganju SA, Goel A. Prevalence of HBV and HCV infection among health care workers (HCWs). J Commun Dis2000; 32:228-30.

\section{AUTHORS:}

1. Sateesh K. Malkappa

2. Sreekanth B.

\section{PARTICULARS OF CONTRIBUTORS:}

1. Assistant Professor, Department of Microbiology, Kamineni Institute of Medical Sciences.

2. Assistant Professor, Department of Microbiology, Kamineni Institute of Medical Sciences.

\section{NAME ADDRESS EMAIL ID OF THE} CORRESPONDING AUTHOR:

Dr. Sateesh K. Malkappa,

Assistant Professor,

Department of Microbiology,

Kamineni Institute of Medical Sciences,

Sreepuram, Narketpally District,

Nalgonda, Andhra Pradesh - 508254, India.

E-mail: drsateesh2006@gmail.com

$$
\begin{aligned}
& \text { Date of Submission: 06/02/2014. } \\
& \text { Date of Peer Review: 07/02/2014. } \\
& \text { Date of Acceptance: 17/02/2014. } \\
& \text { Date of Publishing: 08/04/2014. }
\end{aligned}
$$

